\title{
Historical perspectives of The American Association for Thoracic Surgery: Timothy Joseph Gardner
}

John V. Conte, MD

Timothy J. Gardner (Figure 1), the 82nd president of The American Association for Thoracic Surgery (AATS), was born in Philadelphia on December 6, 1938, and was raised in the Washington, DC, area. He was the son of a high school teacher and athletic coach who later became the director of athletics at Georgetown University. His father, who was also a reserve officer in the US Navy and had interests in business and government relations during his multifaceted career, clearly influenced Dr Gardner with the academic heritage and commitment to the military that he passed on to him. His mother was a homemaker, and he had 2 younger siblings. His sister, Sheila Gardner Mohs, married a classmate of Dr Gardner and raised 4 children in California. His brother, Michael Gardner, was a successful communications policy attorney in Washington, DC.

Dr Gardner's early life and education were profoundly influenced by his Catholic upbringing. He attended Catholic grade school and attended a Jesuit high school before attending Georgetown University for both college and medical school. His faith was so strong that he gave serious consideration to becoming a Catholic priest. He spent time in seminary studying for the priesthood before making the decision to go to medical school. He ultimately decided the religious life was not for him and that he could maintain his personal goal of serving people by transitioning to medicine. He later felt that the opportunity to help others in a time of need made the switch to medicine an easy transition.

\section{PERSONAL LIFE}

Medical school afforded Dr Gardner something far greater than a professional education. It was there that he met a classmate, the former Nina Hooton, who became his wife between their second and third years of medical school. They had the first of their children during their internship, and their family ultimately grew to 4 children: Julie, Joby, Emily, and Nick, none of whom followed their parents into medicine. The Gardners are now the proud

\footnotetext{
From the Division of Cardiac Surgery, Department of Surgery, Johns Hopkins Medical Institutions, Baltimore, Md.

Disclosures: Author has nothing to disclose with regard to commercial support.

Address for reprints: John V. Conte, MD, Division of Cardiac Surgery, Department of Surgery, Johns Hopkins Medical Institutions, 600 N Wolfe St, Blalock 618,

Baltimore, MD 21287 (E-mail: jconte@jhmi.edu).

J Thorac Cardiovasc Surg 2015;149:1477-80

$0022-5223 / \$ 36.00$

Copyright (c) 2015 by The American Association for Thoracic Surgery

http://dx.doi.org/10.1016/j.jtcvs.2015.05.001
}

grandparents of 6 grandchildren, whom they see frequently (Figure 2).

Nina went on to become a pediatrician and was clearly the glue that held the family together during the long and demanding years of surgical training and cardiac surgery practice. Together, they raised a family, had successful careers, and developed a family hobby out of Nina's lifelong passion for breeding and raising race horses. Nina Gardner became world renowned and achieved a fame that has even exceeded Dr Gardner's well-deserved recognition. They participated in many types of equine competition but have achieved particular success in a competition known as "3Day Eventing." They had a horse named "House Doctor" who was delivered by Dr Gardner, the only horse he ever delivered. House Doctor won a gold medal at the Sydney Olympics in 2000 and was voted the "Horse of the Year." Although he has no specific hobbies, Dr Gardner is a voracious reader and is particularly interested in the workings of our government and politics. He does stay fit with a busy lifestyle, including a passion for the outdoors (Figure 3).

Dr Gardner continued a family tradition by joining the Army and enrolling in the Berry Plan during the Vietnam War in 1968. He spent two years, 1968 to 1970, serving as a major with the 5th Field Army Hospital in Bangkok, Thailand. His patient population consisted less of combat patients and more of administrative military and government personnel. His military service came after his internship and interrupted his formal surgical training; however, these years were looked on as a very positive family experience.

\section{SURGICAL CAREER}

\section{Interest in Cardiac Surgery}

In the year between his second and third years of medical school, Gardner worked in the laboratory of Dr W. Proctor Harvey, who was a cardiologist of international fame. This experience kindled his fledgling interest in cardiovascular research, and he became initiated into academic pursuits. He worked for Harvey throughout his third year of medical school and during the summer between his third and fourth years. During this time, he also became profoundly influenced by another cardiovascular giant at Georgetown at the time. Dr Charles Hufnagel, who performed the first successful heart valve implantation in the world, was at the height of his clinical and academic career. His influence led Dr Gardner toward his ultimate choice of a career in academic cardiac surgery. 


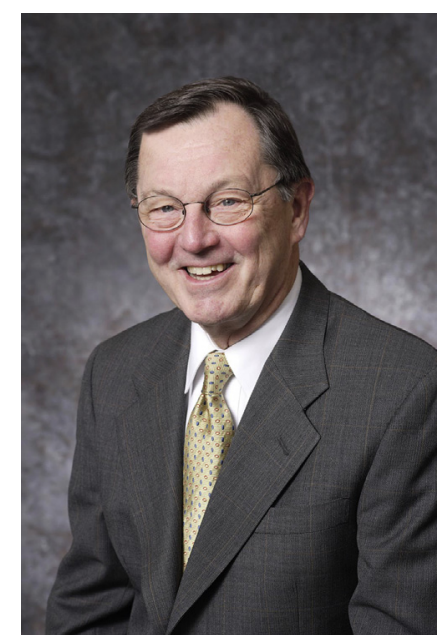

FIGURE 1. Dr Timothy J. Gardner, 82nd president of The American Association for Thoracic Surgery.

\section{Residency Training}

After medical school, Dr Gardner received his surgical training at Johns Hopkins University Hospital in Baltimore. He arrived at Hopkins after Alfred Blalock (30th AATS president) had died, but Blalock's influence was still palpable. After returning from military service, Dr Gardner spent a year, 1970 through 1971, in the cardiac surgery research laboratory at Hopkins, where he fell under the influence of Mr Vivian Thomas, who continued to run the cardiovascular research laboratory and train cardiac surgery residents as he had done since he had come to Hopkins with Dr Blalock in 1941 (Mr Thomas began work with Dr Blalock at Vanderbilt in 1930). ${ }^{1}$ It was this experience that firmly cemented Dr Gardner's decision to pursue a career in academic cardiac surgery. His greatest influence during his formal training was Dr Vincent Gott, who was the chief of cardiac surgery and was himself a Society of Thoracic Surgeons president. Dr Gott became a mentor and lifelong friend. Dr Gardner stated in his AATS presidential address that he was also profoundly influenced by Dr David Skinner (77th AATS president) when he was at Hopkins and by Sir Brian Barratt-Boyes, with whom he trained in New Zealand after his formal training at Johns Hopkins was completed. ${ }^{2}$

\section{Early Career}

After his formal training, Dr Gardner joined the faculty at Hopkins. He performed both adult and pediatric cardiac surgery. He developed a variety of academic interests and had an active laboratory while also performing clinical research. He received many grants, published widely, and achieved national and international acclaim as he climbed the academic ladder, being promoted to full professor in 1986. During this period of his career at Hopkins, he worked closely with Drs Bruce Reitz and William Baumgartner.

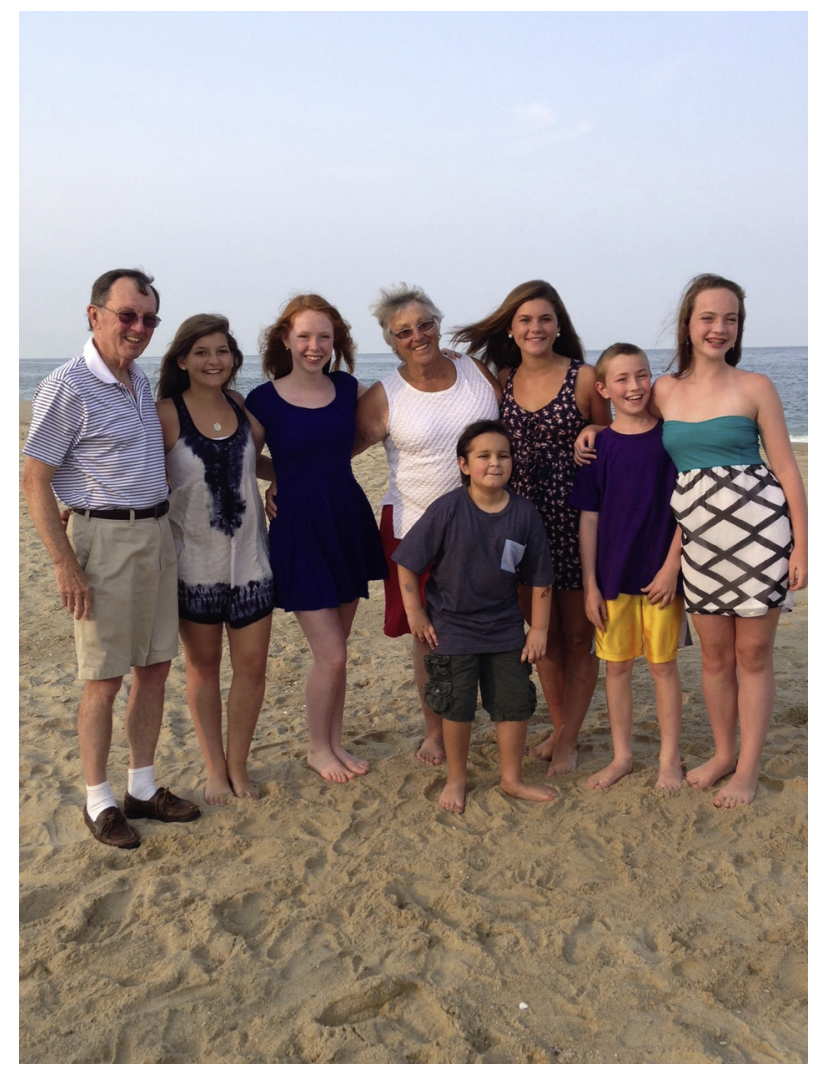

FIGURE 2. Tim and Nina with their grandchildren.

As a result of his close working relationship with them, he stated in his AATS presidential address that he considered himself "a Shumway trainee, once or twice removed." 2 Dr Baumgartner considers Dr Gardner at this time to have been "the consummate teacher, surgeon and investigator" (personal communication, 2015).

\section{Middle Career}

Dr Gardner left Hopkins in 1993 to become the Mosley Professor and the chief of the division of cardiac surgery at the University of Pennsylvania. There he continued his successful clinical and academic career. He trained another generation of students and residents who have gone on to become academic leaders in the field of cardiac surgery.

\section{LATER CAREER}

Dr Gardner made a paradigm shift out of a clinical academic role and into an administrative role when he left the University of Pennsylvania in 2005 to become the medical director of the Christiana Care Center for Heart \& Vascular Health, and in 2011 he became executive director of Christiana Care's Value Institute in Newark, Del. Even in this administrative role, he has maintained his commitment to academic medicine by chairing the steering committee for the Cardiothoracic Surgery Clinical Trials Network, 


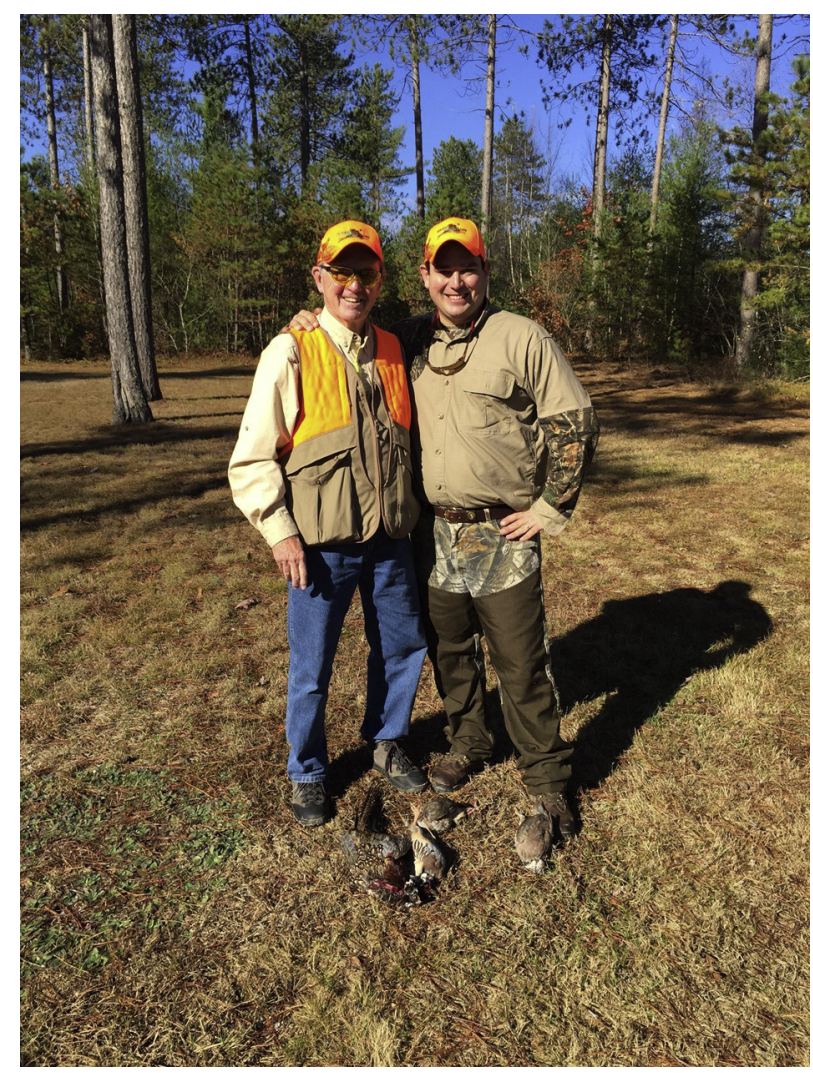

FIGURE 3. Tim enjoying the outdoors on a hunt with his youngest son, Nick.

sponsored by the National Heart, Lung, and Blood Institute. Dr Gardner also serves as a professor of surgery at Jefferson Medical College.

\section{SERVICE ON NATIONAL AND INTERNATIONAL BOARDS AND ASSOCIATIONS}

Dr Gardner served as president of the American Heart Association (AHA) in 2008 through 2009. He is 1 of only 3 surgeons to hold the honor of the AHA presidency, Drs William Glenn and Gerald Austen (69th AATS president) being the other 2. He has been a member of several AHA advisory boards and committees and of the national board of directors, with overall more than 25 years of AHA service. Dr Gardner was president of the AATS in 2001 to 2002, and his presidential address entitled, "Our Heritage and Our Future," was delivered in Washington, DC, on May 6, 2002. ${ }^{2}$ He also served as a director of the American Board of Thoracic Surgery for 10 years and served as the board's vice chair and chair from 2001 through 2005. Dr Gardner has also served in several roles for the National Heart, Lung, and Blood Institute and the National Institutes of Health. He served as an independent practice association medical officer in the division of cardiovascular diseases at the National Heart, Lung, and Blood Institute at the National Institutes of Health from 2004 through 2007.
Dr Gardner has served in many advisory roles for medical organizations, industry, and the federal government, serving from 2008 through 2013 as a Food and Drug Administration special employee for the Anesthetic and Analgesic Drug Product Advisory Committee.

\section{REFLECTIONS ON TRAINING AND ACADEMIC CAREERS}

After having spent his career at 2 of the leading cardiac surgery institutions in the United States, Dr Garner has many thoughts on training and how to develop a successful academic career.* His advice to young surgeons is to concentrate on the clinical aspect of the career first and then move on to the academic and teaching components. Few surgeons, he feels, are fully clinically competent when they finished training, and they need to establish themselves before becoming competent teachers and researchers. To achieve success in all 3 areas of the academic mission, he feels it is important to provide block time so that clinical and research times do not conflict. Dr Gardner notes that it is harder to be a true "triple threat" than it was in his day, and those who wish to be successful need to allocate time to each pursuit.

Dr Gardner feels that the idea of allocating 2 or 3 years to learning cardiac surgery no longer meets the needs of today's trainees in many respects. He feels that there needs to be a lifelong pursuit of learning and training. He feels that time needs to be spent in simulation and that this is an important component of early training, saying, "The time has passed for having to learn surgical skills on patients." Surgery resident do need to perform an appropriate volume of surgery under direct supervision; however, Dr Gardner feels that the emphasis on performing operations alone can detract from learning. Dr Gardner spent time after his residency in Auckland, New Zealand, working with Sir Brian Barratt-Boyes to experience a different approach to cardiac surgery. He observed and assisted but did not do many cases; however, he felt it was a great experience. He feels the experience of visiting other programs and watching master surgeons can be an invaluable part of a trainee's education and a preparation for lifelong learning.

\section{AATS LIFETIME ACHIEVEMENT AWARD}

The Lifetime Achievement Award, one of the most prestigious honors that can be given by the AATS, was presented to Dr Gardner during the 95th annual meeting in Seattle, Wash. The award serves to recognize individuals for their significant contributions to cardiothoracic surgery in the areas of patient care, teaching, research, or community service. Dr Gardner has been a true leader in the field of

\footnotetext{
* All Dr Gardner's reflections and quotations are drawn either from his AATS pas president interview (January 2011, pending publication at the AATS Centennial) or from personal conversations unless otherwise noted.
} 
cardiothoracic surgery and is only the sixth recipient of this prestigious award, joining Drs F. Griffith Pearson, Frank C. Spencer, Thomas B. Ferguson, Eugene Braunwald, and Fred Crawford. It was with great pride that the AATS awarded the Lifetime Achievement Award to Timothy J. Gardner for a distinguished career with contributions in multiple areas that have profoundly benefited the specialty of cardiothoracic surgery.

Dr Timothy J. Gardner has led a life filled with a loving family and a fulfilling clinical and academic career. He was able to fulfill his goal of serving his fellow man. His presidency of the AATS and his lifetime achievement awards are proud accomplishments but are only one aspect of a rich and rewarding life well lived.

\section{References}

1. Thomas VT. Pioneering research in surgical shock and cardiovascular surgery: Vivien Thomas and his work with Alfred Blalock: an autobiography. Philadelphia: University of Pennsylvania Press; 1985.

2. Gardner TJ. Presidential address: our heritage and our future. J Thorac Cardiovasc Surg. 2002;124:649-54. 